
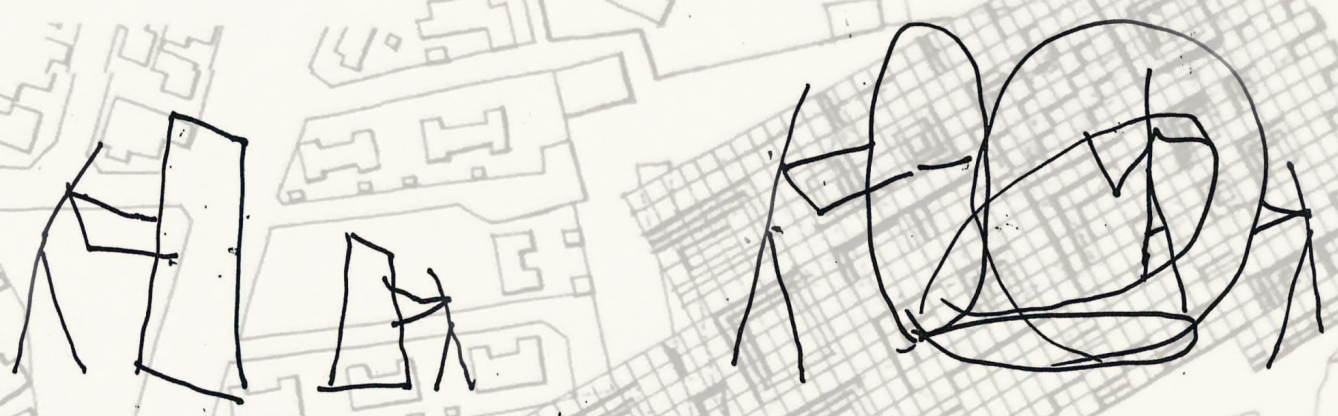
FOR "PEOPLE'S ARGHTECURE' IT MUST BE EASY TO ASSEMBLE

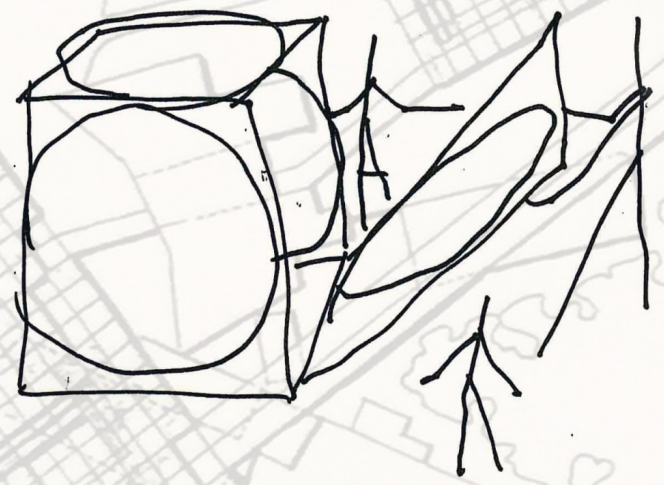

AND EASY TO DIS-ASSEMBLE

AND RE-ASSEMIBLE INTO A DIFFERENT PATIERN

ENTS

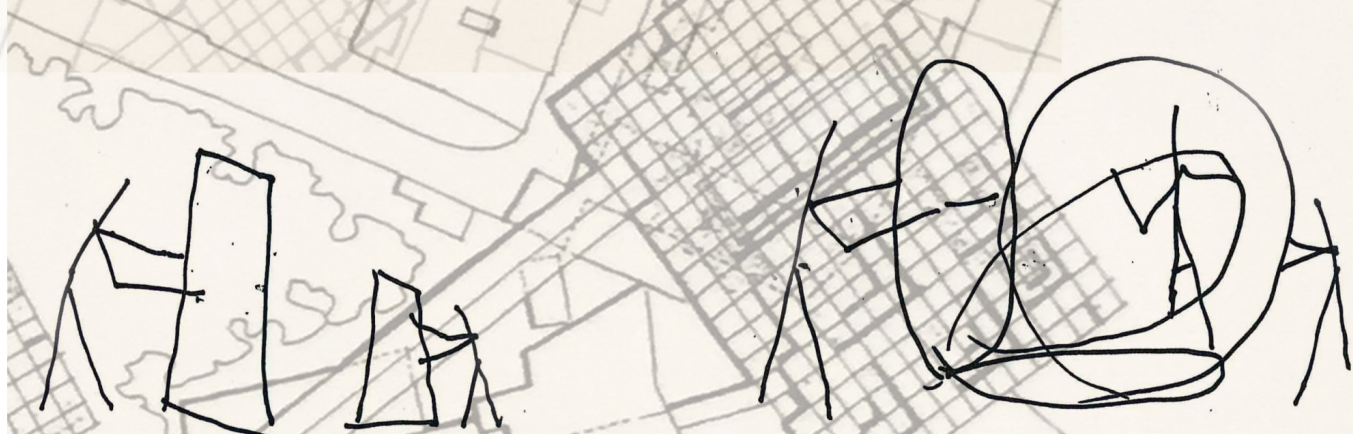

EGR "PEOPLE'S ARCHTECURE'? TOR a LAYMAN TO ASSEMBLE

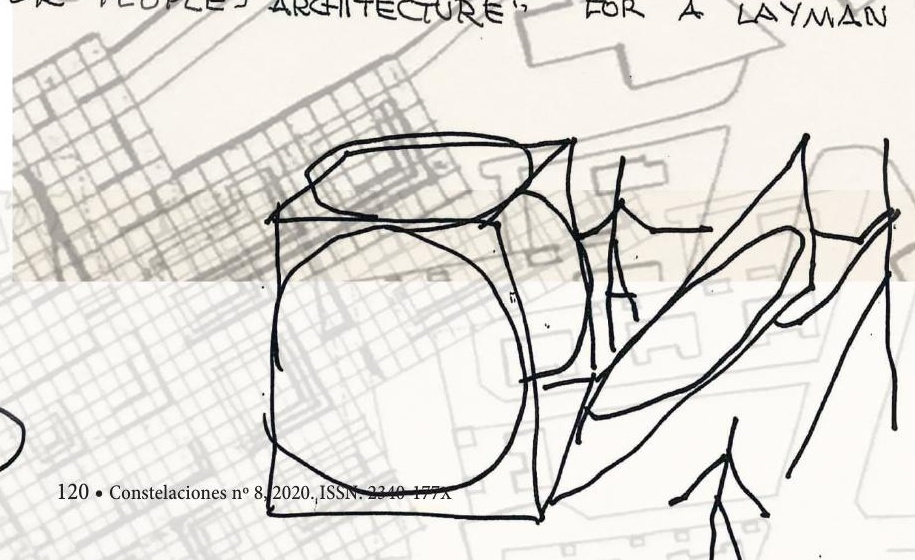




\title{
La cama y el dormitorio. Dos momentos de cambio en la noción de intimidad en Occidente
}

The Bed and the Bedroom. Two Turning Points in the Western Concept of Privacy

\author{
María de Miguel Pastor, Carla Sentieri Omarrementería \\ Universitat Politècnica de Valencia \\ Traducción Translation Anne Barton de Mayor
}

\section{Palabras clave Keywords}

Mueble, privacidad, dormitorio, cama, tecnologías, telecomunicación, trabajo, casa

Furniture, privacy, bedroom, bed, technologies, telecommunications, work, house

\section{Resumen}

El objetivo del presente ensayo es explorar la repercusión de la evolución de la noción de intimidad de la sociedad occidental en el diseño de la cama y su relación con el dormitorio. Para ello, la investigación se centra en dos momentos de inflexión, el siglo XVII y el siglo XX, caracterizados por la aparición y desaparición del dormitorio respectivamente. A lo largo del artículo se expone cronológicamente la idea de privacidad asociada a la casa y se analizan una serie de ejemplos paradigmáticos de camas de ambas épocas. El estudio evidencia que, mientras la cama en el siglo XVII auguraba la llegada de una habitación exclusiva para dormir, las tecnologías dirigen un proceso contrario hacia una cama que retoma su condición de arquitectura interior desvinculada del dormitorio.
Abstract

This paper examines how the changing concept of privacy in western society has affected the design of the bed and its relationship with the bedroom by focussing on two turning points, the 17th Century and the 20th Century, characterised by the appearance and demise of the bedroom respectively. This article outlines the chronological development of the concept of privacy in the home and analyses several illustrative examples of beds in both periods. The authors' research reveals that whereas the 17th Century bed marked the onset of a room specifically for sleeping, modern technologies are reversing this process and turning the bed back into an item of interior architecture dissociated from the bedroom. 
Introducción: los siglos de la cama. El mobiliario ha representado, a lo largo de la historia, las distintas maneras de vivir de cada sociedad. Su uso, configuración y disposición en el espacio proporcionan información acerca de un momento cultural e ideológico concreto. De manera que, una modificación sustancial y consolidada socialmente de algún aspecto del mobiliario es frecuente que corresponda con un síntoma de cambio de costumbres y de mentalidad de las sociedades que hacen uso de él. La vinculación de un mueble con su momento cultural permite establecer semejanzas entre piezas de mobiliario de contextos y sociedades de procedencia heterogénea debido a ciertos paralelismos en sus maneras de vivir y sus formas de pensar.

La historiadora francesa Michelle Perrot, alude en su libro Historia de las alcobas (1) a Henry Havard, que califica el siglo Xvir como "el gran siglo de la cama" por la importancia que ésta adquirió como bien, lo que se tradujo en el notable incremento de camas, tanto en número como en variedad en una misma casa. Por su parte, la historiadora y teórica de la arquitectura Beatriz Colomina publica en 2014 el ensayo titulado The Century of the Bed, en el que califica el siglo xx como "el siglo de la cama" y la define como lugar de trabajo en la era de la telecomunicación. Si la industrialización trajo consigo la separación entre "casa y oficina, descanso y trabajo, noche y día", (2) la postindustrialización devuelve el trabajo a la vivienda, llevándolo hasta el dormitorio y, en particular, a la cama.

La desprivatización de las partes más íntimas de la vivienda debido a los últimos avances tecnológicos permite comparar la época actual con el proceso de privatización que tuvo lugar en las sociedades occidentales entre los siglos XVI y XVIII, momento en que las viviendas pasaron de públicas a privadas y se produjo la separación del lugar de residencia y el de trabajo.

El objetivo del presente ensayo es explorar la repercusión de la evolución de la noción de intimidad de la sociedad occidental en el diseño de la cama y su relación con el dormitorio. Para ello, la investigación se centra en dos momentos de inflexión, el siglo xvir y el siglo xx, caracterizados por la aparición y desaparición del dormitorio respectivamente. A lo largo del artículo

Introduction. The Centuries of the Bed. Over the course of history, furniture has expressed the different lifestyles of different societies. The spatial layout, arrangement and use of furniture offer an insight into specific cultural and ideological moments in time. Consequently, any considerable alteration to furniture that becomes widely accepted by society often reflects a change in the habits and mindset of the societies in which it is used. The link between furniture and its cultural era make it possible to pinpoint similarities between items of furniture from different backgrounds and societies due to certain parallels that can be drawn between their lifestyles and ways of thinking.

In her book Histoire de chambres (1) the French Historian Michelle Perrot writes that Henry Havard describes the 17th Century as the "great century of the bed" due to the importance the bed gained as a possession, leading to a considerable increase in the number and variety of beds in a single household. In 2014, the Historian and Architectural Theorist Beatriz Colomina published the paper The Century of the Bed, (2) in which she describes the 20th Century as the "century of the bed" and defines it as a workspace in the telecommunication era. "Industrialization brought with it the eight-hour shift and the radical separation between home and office/factory, rest and work, night and day. Post-industrialization collapses work back into the home and takes it further into the bedroom and into the bed itself".

The deprivatisation of the most private parts of the home as a result of the latest technical developments enables the present time to be compared with the privatisation process that happened in western societies between the 16th and 18th Centuries, a period when homes shifted from public to private realms and a division occurred between living quarters and workplaces. 
se expone cronológicamente la idea de privacidad asociada a la casa y se analizan una serie de ejemplos paradigmáticos de camas y dormitorios de ambas épocas.

Con el avance de la conciencia de privacidad en Occidente, las camas muestran una evolución en la que llegan a sobrepasar la condición de muebles, constituyendo verdaderos híbridos entre mueble y estancia, para desembocar en la aparición del dormitorio. El estudio evidencia que, mientras la cama en el siglo XVII auguraba la llegada de una habitación exclusiva para dormir, las tecnologías dirigen un proceso contrario hacia una cama que retoma su condición de arquitectura interior desvinculada del dormitorio. Frente a los estudios previos, de los que parte el presente estudio, sobre la evolución de la idea de privacidad en el ámbito doméstico, $(3,4)$ la evolución del dormitorio y sus formatos $(5,6)$ y la influencia de los medios de comunicación en la casa, $(7,8,9)$ el artículo se centra en el mueble más íntimo -la cama- y sus distintas manifestaciones en dos momentos ideológicos y culturales concretos.

El dormitorio como foco social. En el siglo xv surgió la devoción por los bienes materiales y los espacios domésticos de los más pudientes comenzaron a amueblarse paulatinamente, haciendo uso de los objetos para indicar la posición social, además de para cumplir una función determinada. Este efecto fue particularmente significativo en la estancia que albergaba la cama, escogida como foco para expresar el nuevo apego a las posesiones. El extraordinario amueblamiento de la alcoba llevaba aparejado una actividad intensa. (10) (Fig. 1) Su carácter público junto con los primeros brotes de un sentimiento de privacidad, hicieron que las estrategias aplicadas en su sofisticación se orientasen a aislar la pieza de la cama dentro de una estancia de uso ambiguo, dotándola de una entidad tal que la convirtieron en un híbrido entre mueble y estancia. Aunque el origen del dosel tiene que ver con la necesidad de resguardarse del frío, su incorporación a la cama llevaba implícita una voluntad de aislamiento frente a la multifuncionalidad de la estancia que ocupaba. (11) El mueble

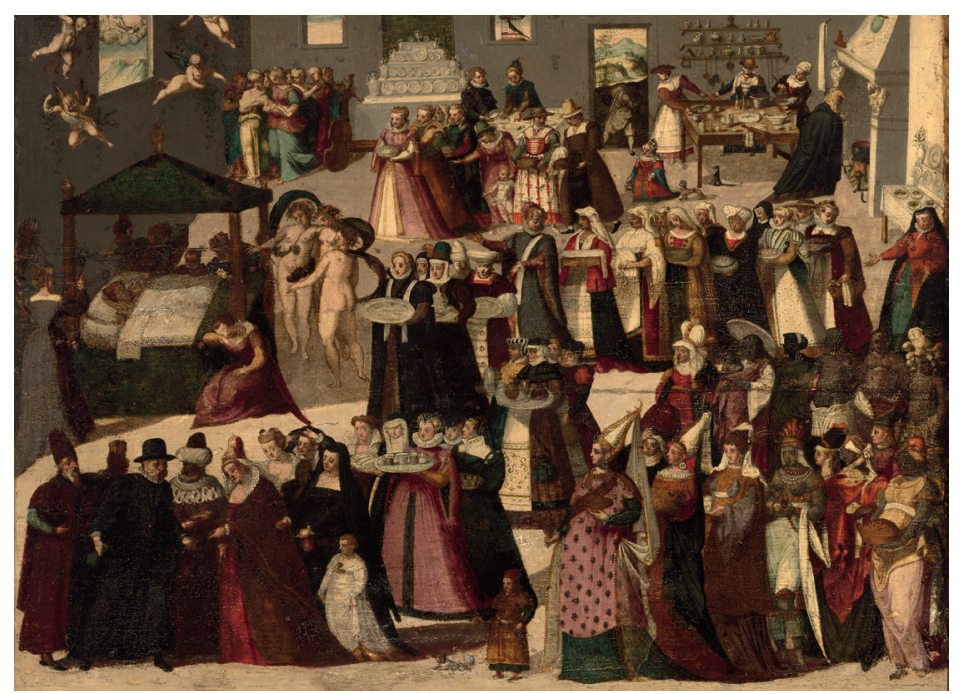

Fig. 1. Anónimo. The Birth of Caterina Cornaro, siglo XVI. Isabella Stewart Gardner Museum. 
aumentó en tamaño y se completó con accesorios como consecuencia de la búsqueda de un espacio reservado en la cámara, mostrando su máxima expresión en el siglo XVII.

El desarrollo de la noción de intimidad. Hasta la llegada del estado moderno no existió una noción de intimidad en la conciencia del individuo. Las viviendas medievales presentaban un carácter público, y no privado; estaban llenas de gente y aglutinaban una gran variedad de usos. Trabajo y ocio formaban parte de la vivienda. (Fig. 2) La no especificidad de funciones a escala urbana se plasmaba asimismo en la escala arquitectónica, de manera que, pese a la variedad de tareas que concentraba la vivienda, todavía no existían habitaciones destinadas a un uso específico ni habitaciones privadas. Aunque podría relacionarse la ausencia de habitaciones

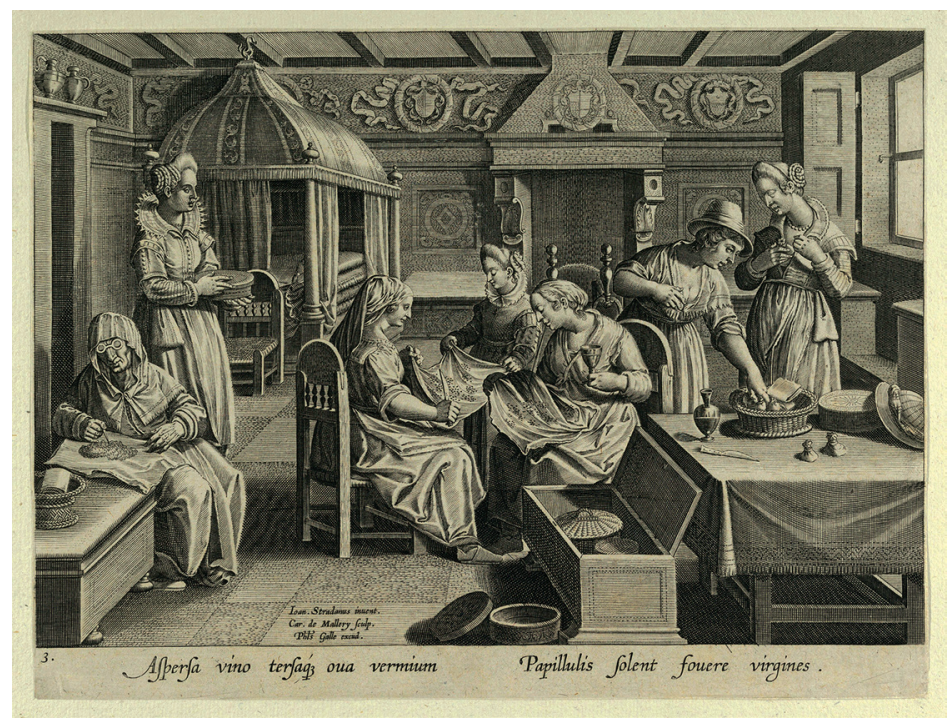

Fig. 2. Van Mallery, Karel. The Incubation of the Silkworm Eggs, lámina 3 de 'The Introduction of the Silkworm, 1595.

This paper aims to examine the impact that changes in the concept of privacy in western society had upon the design of the bed and its relationship with the bedroom by focussing on two turning points: the 17th Century and the 20th Century, characterised respectively by the appearance and demise of the bedroom. This article offers a timeline of the concept of privacy in the household and an analysis of a series of illustrative examples of beds and bedrooms in both periods.

As the concept of privacy developed in the West, beds ceased to be merely items of furniture and evolved into veritable furniture/bed hybrids that led to the appearance of the bedroom. The authors' research reveals that whereas the 17th Century bed marked the onset of a room specifically for sleeping, modern technologies are reversing this process and turning the bed back into an item of interior architecture dissociated from the bedroom.

Unlike the earlier studies on which the present paper is based, about the evolution of the concept of privacy in the home, (3) (4) the evolution of the bedroom and its different formats, (5) (6) and the impact of the media upon the home, (7) (8) (9) the paper herein focuses on the most intimate of all items of furniture -the bed-in its different forms at two specific cultural and ideological moments in time.

The Bedroom. A Hub of Social Interaction. The 15th Century saw an upsurge in the love of belongings, and the households of the wealthy gradually began to be furnished with items that not only fulfilled specific purposes but also conveyed their social standing. This was particularly evident in the room containing the bed, this being the room chosen to 
privadas en las viviendas con la escasez de medios, este hecho se debía más bien a que la privacidad era algo desconocido por sus habitantes, pues incluso las viviendas de los más ricos no disponían de estancias especializadas. (12)

Entre los siglos XVI y XVIII la mentalidad comenzó a cambiar y tuvo lugar un proceso de privatización de las viviendas en las sociedades occidentales, que derivó en la invención del ámbito privado moderno. El desarrollo de la noción de intimidad tuvo, inevitablemente, repercusión en las viviendas. A partir de la gran sala medieval pública que aglomeraba todas las funciones comenzaron a aparecer estancias más específicas con los usos anteriormente asignados a algunos objetos de mobiliario. (13) En esta evolución, el mueble pasó a complementarse con receptáculos, cajones, o pequeñas puertas, como expresión de apropiación del lugar y de una creciente demanda de privacidad, llegando a constituir un espacio acotado en la cámara, o incluso una habitación anexa o autónoma a ésta. No obstante, el dormitorio como espacio destinado únicamente a dormir, y oculto de la visión del público, no apareció hasta la segunda mitad del siglo xviII debido a la importancia que adquirió como núcleo social de la vivienda y como expresión de la posición de sus habitantes. (14)

La cama con voluntad de alcoba. La configuración de la cama en el siglo XVII resultó de dos aspiraciones contrapuestas: el afán por mostrarla y el deseo de cierta intimidad frente a la gran vida social del espacio que ocupaba, ya que en él se recibían visitas, se debatía, se comía, e incluso se impartía justicia.

Paralelamente, se encontraban otros tipos coetáneos de camas que adquieren la configuración de una pequeña habitación dentro de otra. Por ejemplo, la cama neerlandesa adoptó el formato de nicho, cerrada por tres lados. A juzgar por algunas pinturas de la época como las del pintor holandés Pieter de Hooch, la cama todavía no formaba parte de una habitación privada y específica. Así, en su pintura The Bedroom, (Fig. 3) aunque el título exprese una habitación destinada a dormir, la estancia aparece como un espacio multifuncional y de uso también diurno.

demonstrate this new fondness for possessions. The remarkable furnishings found in such rooms were accompanied by considerable activity. (10) (Fig. 1) The public nature of such rooms together with an incipient desire for privacy meant that the methods applied to make them more sophisticated focussed on transforming the bed into an imposing island, halfway between a piece of furniture and a chamber, inside a room whose purpose was unclear. Although canopies were originally added to beds to keep the occupants warm, they were also intended to seclude them from the many activities taking place in the same room. (11) Beds increased in size and were enhanced with accessories designed to create a private space within the chamber, a trend that reached its maximum expression in the 17th Century.

The Development of the Concept of Privacy. Until the onset of the modern state, the concept of privacy did not exist in the mind of the individual. Medieval dwellings were not private places but public areas bustling with people and a wide range of activities. Work and leisure were part of the dwelling. (Fig. 2) The blurred lines of urban occupations were also to be seen in architecture, hence, despite the multitude of tasks taking place in houses, there were still no rooms earmarked for specific purposes or any private rooms. Although this lack of private rooms in houses might be thought to stem from poverty, it was more due to the fact that privacy was unknown to their inhabitants, as even the homes of the wealthiest had no rooms for specific purposes. (12)

Between the 16th and 18th Centuries, attitudes began to change, and privacy began to prevail in dwellings in western societies, leading to the invention of the realm of modern privacy. The development of this concept inevitably had an impact on dwellings. The great hall of the Middle Ages, a public area where all sorts of activities took place, was gradually replaced by more specific 


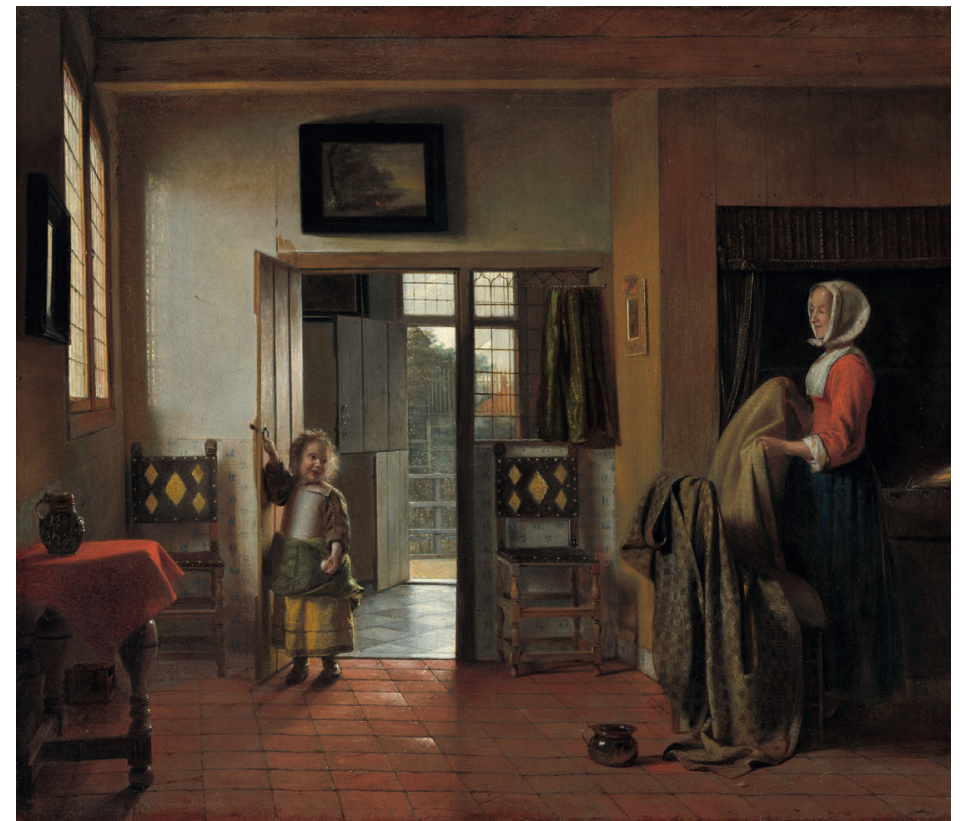

Asimismo, la versatilidad del dormitorio es representada con frecuencia en los grabados de Abraham Bosse, donde la cama se aloja en una caja de tela compartiendo espacio con la mesa de comedor. Otro ejemplo contemporáneo lo constituye la cama cerrada bretona, cuyos orígenes se encuentran en el siglo XVII. Ésta se asemejaba a un armario para dormir, cerrada por sus tres lados y con dos puertas correderas, algunas de ellas incluso podían cerrarse desde dentro gracias a un "sólido gancho", (15) y así asegurar un espacio resguardado e íntimo en una sala común. A juzgar por sus elementos, como puertas y cerraduras, la solución adoptada se aproxima más a la de una celda que a la de una cama.
Fig. 3. De Hooch, Pieter. The Bedroom, 1658. Arthur K. Wheelock Jr., Pieter de Hooch/The Bedroom/1658/1660, Dutch Paintings of the Seventeenth Century, NGA Online Editions.

rooms where occupations previously related to certain items of furniture were carried out. (13) During this evolution, furniture acquired receptacles, drawers and small doors that conveyed an appropriation of the place and an increasing demand for privacy, and gradually evolved into a delimited space in the chamber or even an adjoining or separate room. Nonetheless, the bedroom did not evolve into a secluded place just for sleeping until the latter half of the 18th Century due to the importance it had acquired as a hub of social interaction in the dwelling and an expression of the social standing of its occupants. (14)

The Bed as a Bedchamber. The format of the bed in the 17th Century was a product of two contradictory intentions: an eagerness to show it off and a wish for some privacy from the hectic social life taking place in the room it occupied, this being the room for welcoming visitors, holding discussions, eating food and even passing judgement.

Meanwhile, other types of contemporary beds evolved into a sort of small room in another room. The Dutch bed, for example, was shaped like a cubicle enclosed on three sides. Judging by some paintings from that period, such as those by the Dutch painter Pieter de Hooch, the bed was not yet part of a specific, private room. Despite its title, his painting The Bedroom (Fig. 3) depicts a multipurpose room also used during the day.

Bedroom versatility is also often depicted in Abraham Bosse's engravings which show the bed inside an upholstered box in the same room as a dining-room table. Another contemporary example is the Breton box bed dating back to the 17th Century. This bed resembled a cupboard for sleeping in, with walls along three sides and two sliding doors, 


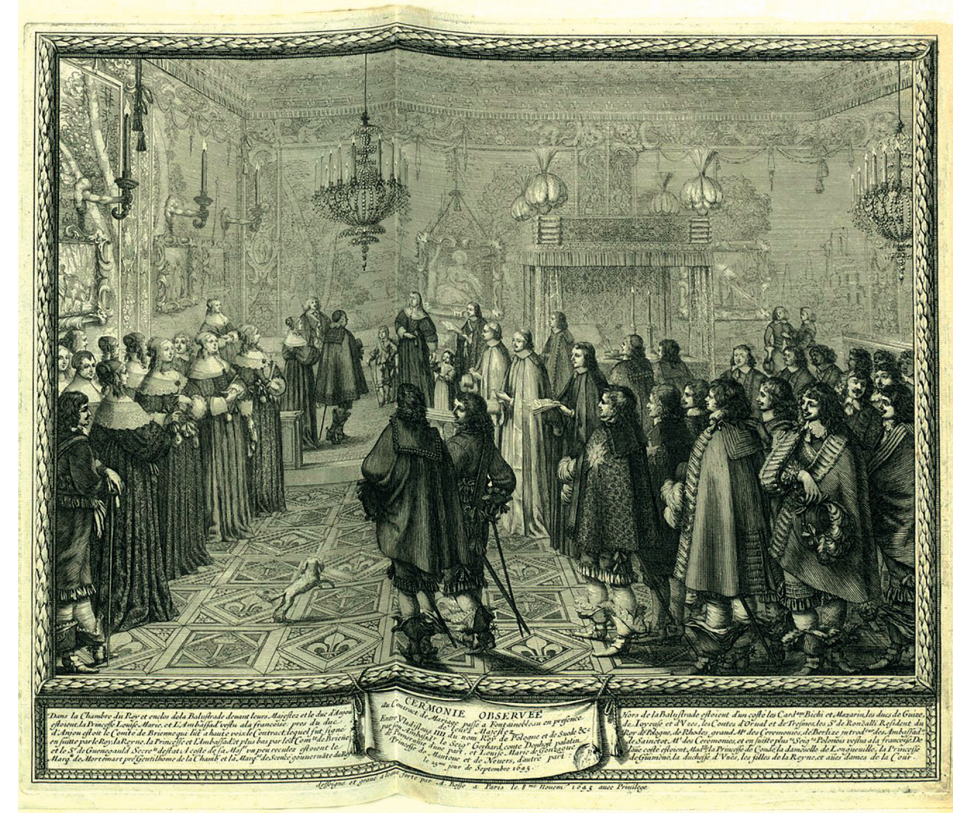

En otros casos, la cama adquirió tal simbolismo que se utilizaba como pieza de recepción. En su escalón más alto, se encuentran los 'lechos de justicia', (Fig. 4) desde donde impartían justicia los grandes señores franceses. Es particularmente destacable el caso de la cama de Luis XIv. Su importancia y repercusión a nivel político y social van acordes con su configuración, elementos y ornamentación. La incorporación a la cama de piezas como columnas, escalones o balaustres, así como sus dimensiones, acercan la pieza al ámbito de la arquitectura más que al del mobiliario.
Fig. 4. Bosse, Abraham. Le Mariage de la reine de Pologne, 1645. Bibliothèque Nationale de France.

sometimes fitted with a big hook (15) to close them from the inside to create a private, sheltered space in a communal chamber. Judging by its constituent parts such as doors and locks, the result resembles a cell more than a bed.

In other instances, beds were so symbolic that they were used as reception rooms. The highest echelon of such items was the 'bed of justice' (Fig. 4) where French lords administered justice. Louis XIV's bed is particularly noteworthy. Its size and impact in political and social terms are in keeping with its format, composition and decoration. With the addition of columns, steps and bannisters, and likewise its dimensions, this bed was more of a building than a piece of furniture.

The Rise of the Bedroom and the Fall of the Bed. From the 17th Century onwards, the house gradually ceased to be a public realm. By the early 19th Century it had become a private refuge differentiated from the city. (16) The separation of workplaces from dwellings caused the home to become a private realm and this led to the house being split into rooms for specific purposes and, also, the appearance of the corridor. (17)

The housing crisis that had affected European cities since the industrial revolution worsened after World War I. The need to make the very most of every square yard made functionalism a success. Many of the minimal dwellings proposed by modern architects at the second CIAM, often resulted in smaller homes for middle-class families featuring distinct living areas. (18) The room most affected by the lack of space and compartmentalisation of the house was the bedroom. It became smaller and was side-lined to less advantageous locations to the benefit of the sitting room. The bedroom lost its typical objects, 
La aparición del dormitorio y el declive de la cama. A partir del siglo XviI se redujo paulatinamente la presencia pública en la casa, de modo que a principios del siglo xIx ya constituyó un refugio privado diferenciado de la ciudad. (16) La separación del lugar de trabajo y de residencia lleva consigo la privatización de la casa, que deriva en su división en habitaciones de usos específicos y en la incursión del pasillo. (17)

Tras la primera Guerra Mundial, la crisis de vivienda que caracterizó las ciudades europeas desde la revolución industrial se intensifica. La necesidad de aprovechamiento de cada metro cuadrado hizo que triunfara el funcionalismo. Las soluciones planteadas por los arquitectos del Movimiento Moderno en el segundo CIAM sobre vivienda mínima, supusieron en muchos casos una reducción en superficie de la vivienda burguesa zonificada destinada a la unidad familiar. (18)

Con la zonificación de la casa y la escasez de espacio, el dormitorio es el sacrificado de la vivienda tanto en dimensiones como en ubicación en favor de la sala de estar; aquél pierde sus objetos característicos, la diversidad de sus piezas de mobiliario y la multifuncionalidad que le caracterizaba anteriormente. (19) La división de la casa por zonas hace que las habitaciones queden relegadas a la 'zona de noche' y que su importancia no vaya más allá del número de habitaciones que componen la vivienda. (20) Las dimensiones alcanzadas en algunas habitaciones resultan equiparables a las de las camas del siglo XVII pues, en algunos casos, estas últimas llegan a medir tres metros de ancho. (21) Con la aparición del dormitorio, la cama simplifica sus formas, pierde su ornamentación, disminuye su tamaño y se rebaja. El cambio fundamental corresponde a la pérdida de su envolvente, redundante una vez la cama ha sido encerrada entre las paredes del dormitorio.

Paralelamente, el individualismo se refleja en otros proyectos contemporáneos que se alejan de las soluciones de viviendas zonificadas estandarizadas para un núcleo familiar. El proyecto de las casas-patio desarrollado entre 1931 y 1938 fue concebido por Mies Van der Rohe para ser habitado individualmente, pues

different items of furniture and its previous multipurpose nature. (19) In compartmentalised houses, bedrooms were relegated to the night zone and the only reason they mattered was the number of bedrooms in a house. (20) Some bedrooms were similar in size to certain 17th Century beds up to three metres wide. (21) With the appearance of the bedroom, the bed became smaller and lower, simpler in shape and less ornate. The main change is the disappearance of the envelope around the bed, an element rendered unnecessary for a bed enclosed by bedroom walls.

In the meantime, individualism was reflected in other contemporary projects quite different from the standard, compartmentalised family homes. The patio houses in the project that Mies developed between 1931 and 1938 were intended for just one occupant: none of these houses had more than one bed. These houses featured a seamless layout which absorbed the bedroom. (22) Whilst intended for quite different occupants, the atomisation of individuals is conveyed by the photograph of the staging of a bedroom taken by Hannes Meyer. (Fig. 5) This photograph not only expresses the precariousness of the moment by showing a room reduced to the minimum, but also reveals a reaction to middle-class housing with well-defined zones by dissociating the bedroom from the house and complementing it with shared services as suggested by the title of this photograph. (23) In this instance, paradoxically, individualism was taken to such extremes that collectivisation became necessary: a foresight of later approaches.

The Smart Bed and the Demise of the Bedroom. In the latter half of the 19th Century, technological developments and improved standards of living caused a shift in the values of Modern Architecture promoted by Team 10, which queried 
en ninguna de las casas hay más de una cama; las casas se organizan como un medio continuo en el que el dormitorio desaparece. (22) Aunque para un usuario muy distinto, la atomización de los individuos viene expresada en la fotografía realizada por Hannes Meyer de la escenografía de una habitación. (Fig. 5) La fotografía no solo representa la precariedad del momento con una habitación reducida a lo mínimo, sino que manifiesta una reacción a la vivienda burguesa zonificada al descontextualizar el dormitorio de la vivienda y complementarla con servicios colectivos, tal y como da a entender el título que le asigna a su fotografía. (23) Aquí, paradójicamente, el individualismo se lleva hasta tal punto que necesita de la colectivización, lo que anticipa los planteamientos posteriores.

La cama telemática y la desaparición del dormitorio. Durante la segunda mitad del siglo XIx, los avances tecnológicos y las mejoras en las condiciones de vida conllevan un cambio en los valores para la arquitectura moderna impulsados por el Team $\mathrm{X}$, que cuestionan algunas ideas como la vivienda mínima estandarizada para un usuario universal o la estricta zonificación funcional de la Carta de Atenas. (24)

En La Casa del Futuro, de Alison y Peter Smithson, el espacio de la cama queda abierto al resto de la vivienda y el usuario principal ya no es la familia. No obstante, su principal aportación es la incursión de las últimas tecnologías electrónicas disponibles, como el teléfono o la televisión, que la abren al resto del mundo. (25)

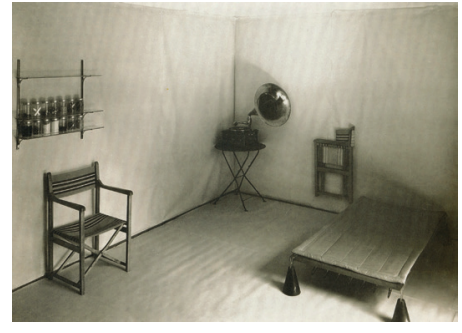

Fig. 5. Meyer, Hannes. Co-op Interieur, 1926. Deutsches Architekturmuseum, Frankfurt am Main.

En este contexto, la apertura del espacio doméstico repercute en el mobiliario, que pasa a asumir las funciones específicas de las habitaciones de la casa. Por ejemplo, Joe Colombo diseña para su propio apartamento una 'máquina' para comer y otra para dormir, de manera que transforma las zonas de la casa en dos objetos instalados en un espacio único. La cama concentra las piezas de mobiliario que le pertenecían al dormitorio. (26) (Fig. 6)

Otro caso representativo de esta idea es la cama Hugh Hefner, director de la revista Playboy, que en la década de los sesenta traslada su oficina a su cama, convirtiendo el mueble en lugar de trabajo diseñado como una pequeña pieza de

concepts such as the minimum, standardised dwelling for a universal occupant and the strictly defined zoning for different uses set forth in the Athens Charter. (24)

In Alison and Peter Smithson's House of the Future, the area for the bed opens out into the rest of the house and the intended occupant is no longer the family. Their main contribution, however, is their foray into the latest electronic technology then available, such as the telephone and television, which connect the bed to the rest of the world. (25)

Against this backdrop, the opening up of household space had an impact on furniture which then assumed the functions of the different rooms in the house. Joe Colombo, for example, designed two 'machines' for his own apartment -one for eating and another for sleeping- thus transforming the areas in his home into two objects installed in a single area. All the bedroom furniture is incorporated into the bed. (26) (Fig. 6)

Another archetypal example of this concept is Hugh Hefner's bed. In the 1960s, the director of Playboy magazine moved his office to his bed, transforming this piece of furniture into a workplace designed as a small architectural unit. (Fig. 7) This bed questions the traditional divide between professional and personal realms (27) whilst anticipating the experimental projects developed by architects in the 1960s for the new connected nomads such as 'high-performance beds' fitted with media connections, (28) i.e. individual capsules or cells created around the globe by architects and designers such as metabolists in Japan, Yona Friedman in France, Archigram in England and Archizoom in Italy, to name but a few. 

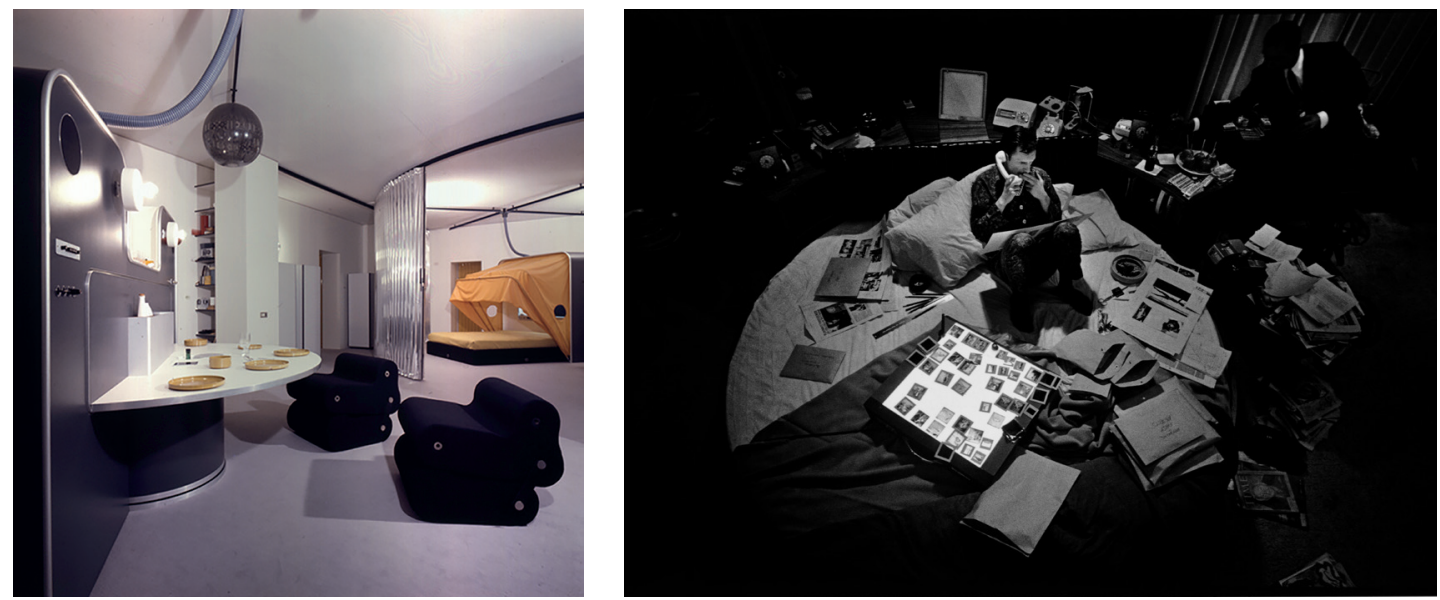

arquitectura. (Fig. 7) El mueble supone una crítica a la oposición tradicional entre los ambientes profesionales y privados (27) a la vez que adelanta los proyectos experimentales de los arquitectos de la década de los sesenta para los nuevos nómadas telemáticos, como 'camas de alto rendimiento' complementadas con los medios de comunicación. (28) Se trata de celdas o cápsulas individuales, que surgen de manera globalizada de la mano de arquitectos y diseñadores como los metabolistas en Japón, Yona Friedman en Francia, Archigram en Inglaterra o Archizoom en Italia, entre muchos otros. Piezas mínimas y transportables, a caballo entre mueble y arquitectura como Inflatable Suit-Home de David Green, Cushicle de Michael Webb, Capsule Home de Warren Chalk -todos del grupo Archigram-, o las cápsulas para la torre Nagakin del Kurokawa construida en 1972, (Fig. 8) una de las pocas de estas utopías llevadas a la realidad.

Lo público se funde con lo privado y desaparece la zonificación, como formula el grupo Archizoom Associati en el proyecto No-Stop City: Residential Car Park, (Fig. 9) que consiste en una metrópolis homogénea e infinita, en donde la casa se

Fig. 6. Colombo, Joe. Vista general del apartamento de Joe Colombo en Milán, 1970. Ignazia Favata-Studio Joe Colombo. Fig. 7. Glinn, Burt. Hugh Hefner, Fundador de Playboy hablando por teléfono en su cama circular, 1966. Magnum Photos.

Tiny, transportable units halfway between furniture and buildings such as David Green's Inflatable Suit Home, Michael Webb's Cushicle and Warren Chalk's Capsule home (all members of the Archigram group), or the capsules in Kurokawa's Nagakin Tower built in 1972, (Fig. 8) one of the few of these utopian concepts that was actually built.

The blurring of public and private realms and the elimination of zonification are two of the precepts put forward in NoStop City: Residential Car Park, (Fig. 9) a project by the Archizoom Associati group consisting of a never-ending, homogeneous metropolis in which the home is broken down into an inhabitable piece of furniture plus a series of objects. This way of living is researched by Toyo Ito in his project Dwelling for a Tokyo Nomad Woman consisting of a sort of tent with a bed in the middle surrounded by another three pieces of furniture: the smart unit (for getting information about the city), the dressing table and the unit for snacks. (29) The house is no longer an indoor area divided into distinct zones, household functions are now scattered around the city. Ábalos (30) describes the nomad woman as a "parasite in the city [...] who blurs the boundaries of her home and her privacy". (Fig. 10)

The miniaturisation of electronic devices that are used in bed jeopardises the original purpose of the bedroom as a private place used only for sleeping. Likewise, the use of digital devices connected to the entire world alters the nature of the bed by multiplying its functions -functions which are, moreover, public-. The bed of today equipped with the latest information communication technology makes the mid-20th Century dream of a connected home a reality. (31) 
disgrega y pasa a ser un mueble habitable más una serie de objetos. Esta forma de vida es investigada por Toyo Ito a través de su proyecto El Pao Para Las Muchachas Nómadas de Tokio. El pao o cabaña incluye la cama en su centro y otros tres muebles a su alrededor: el mueble inteligente (para obtener información de la ciudad), el mueble tocador y el mueble para la comida ligera. (29) La casa ya no es un interior zonificado, sino que las funciones domésticas se disgregan por la ciudad. Ábalos (30) describe a la chica nómada como un parásito en la ciudad “[...], quien borra los límites de su casa y su privacidad". (Fig. 10)

La miniaturización de los dispositivos electrónicos y su uso desde la cama ponen en crisis el sentido original del dormitorio como lugar privado y exclusivo para dormir. Asimismo, la conexión establecida a partir de los aparatos digitales con cualquier parte del mundo modifica el carácter de la cama por la multiplicación de sus funciones y la naturaleza pública de estas. Hoy en día, la cama complementada con las últimas tecnologías de la comunicación hace realidad la fantasía de domesticidad conectada de mediados del siglo pasado. (31)

Conclusión: la pérdida de privacidad y la cama-habitación. Si la industrialización y la segregación del espacio de trabajo y residencia trajeron la privacidad a las viviendas y propiciaron la aparición del dormitorio, la vuelta del trabajo al ámbito doméstico a raíz de los últimos avances tecnológicos produce una desprivatización que lleva de nuevo a la desaparición del dormitorio. Si bien en la desaparición del dormitorio juegan un papel fundamental los motivos económicos y la falta de espacio, Perrot atribuye principalmente el hecho a la pérdida de su "dimensión antropológica". (32) Las condiciones sociales que llevaron a la aparición de la casa privada, como la separación de residencia y trabajo o la concepción de la familia, han cambiado más en los últimos cincuenta años que en los pasados cuatro siglos. (33)

Los diseños de las habitaciones como cápsulas son comparables con los modelos de camas del siglo XVII, en tanto que presentan el formato de piezas híbridas entre mueble y recinto en un interior de carácter público. Asimismo, dos de los máximos exponentes de dichos periodos -la cama de Luis xiv y la

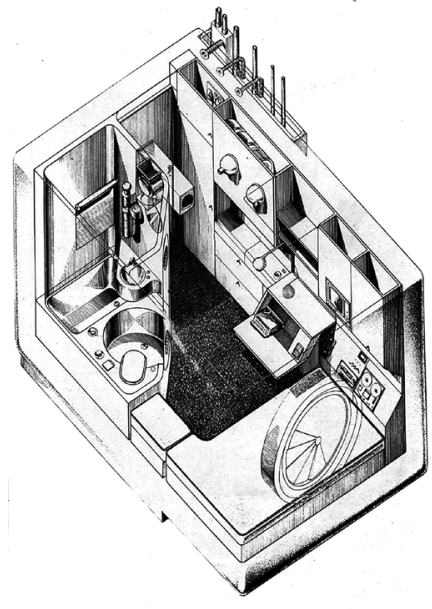

Fig. 8. Kurokawa, Kisho. Axonometría de la cápsula de la torre Nagakin, 1972. Kisho Kurokawa Architect \& Associates.

Fig. 9. ARCHIZOOM. No-stop City, 1971. Montaje de los autores de tres páginas del artículo 'No-stop City' en la revista Domus, n. ${ }^{\circ} 496$, marzo 1971.
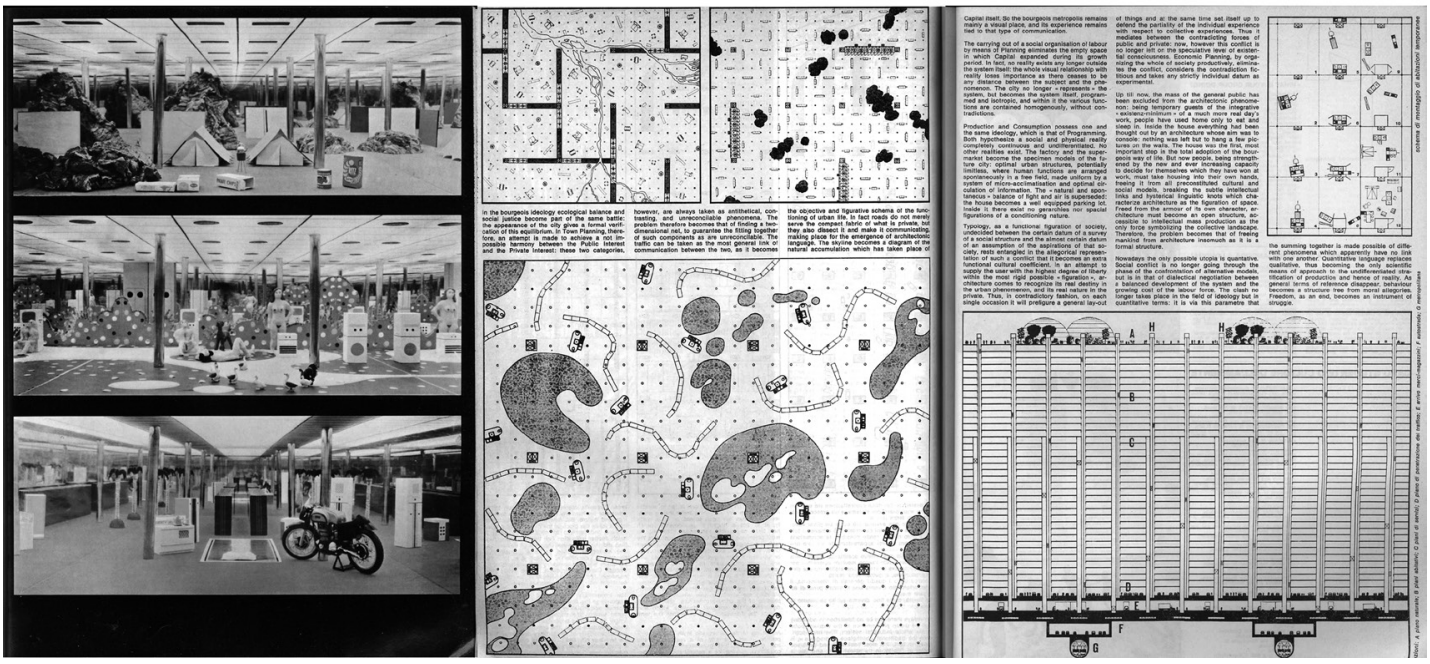


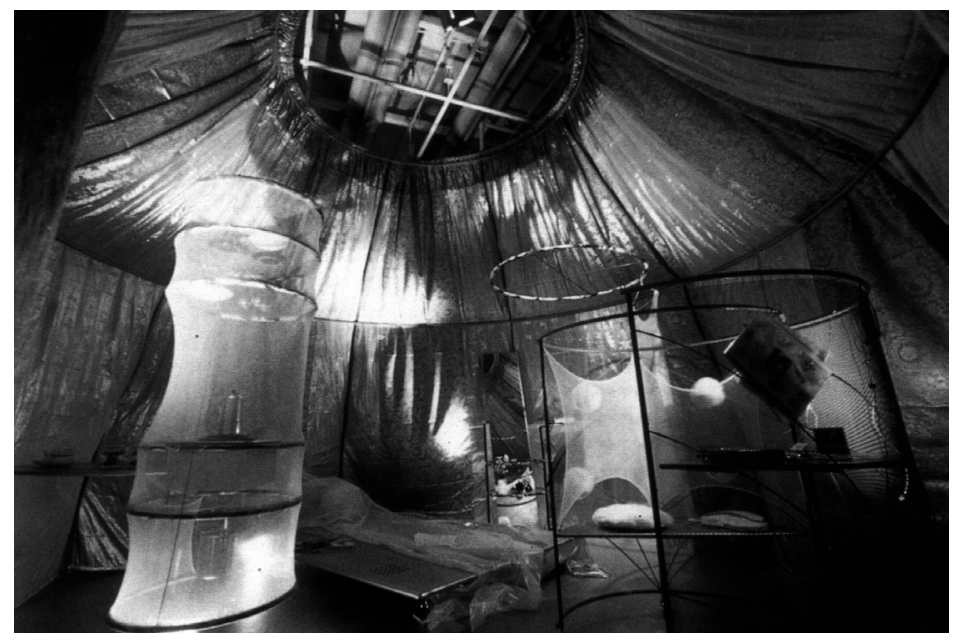

de Hugh Hefner- muestran similitudes en sus funciones, pues en ambas se trabaja desde ellas y ejercen una influencia más allá del ámbito doméstico: "la cama playboy superpone a esta estructura capsular y prostética una arquitectura de poder que proviene de la función tradicional que la cama real había desempeñado hasta el siglo XviII". (34)

El artículo constata la relación entre la mentalidad de la sociedad, la distribución la casa y la zonificación de la ciudad, con la configuración que adopta la cama en dos momentos de cambio ideológico concretos. Las tecnologías de la comunicación repercuten en todos los niveles del habitar y abren un campo de exploración para la cama conectada telemáticamente y desvinculada del dormitorio, que urge a iniciar un 'viaje', esta vez, 'alrededor de la cama'. (35)
Fig. 10. Ito, Toyo. Pao 1. Vivienda para la Mujer Nómada de Tokyo, 1985. Ábalos, Iñaki; Herreros, Juan. 'Toyo Ito: el tiempo ligero'. El Croquis, n. 71, 1995, p. 47.

Conclusion. The loss of privacy and the bed as an entire room. Industrialisation and the separation of the workplace from living quarters endowed the home with privacy and prompted the appearance of the bedroom. However, when recent technological developments enabled people to work from home again, the ensuing deprivatisation led once again to the demise of the bedroom. Although the decline of the bedroom is affected by a lack of funds and space, Perrot believes the main factor to be the loss of its "anthropological dimension". (32) The social conditions that led to the appearance of the private house, such as the separation of the home and workplace or the concept of the family, have changed more in the last fifty years than in the last four centuries. (33)

Capsule-type bedrooms are similar to the 17th Century beds mentioned earlier insofar as they are both hybrids halfway between a piece of furniture and an enclosed space in a public interior. In addition, two of the finest examples of each period Louis XIV's bed and Hugh Hefner's bed- were both used for similar purposes: both were workplaces whose impact extended beyond the household realm. According to Beatriz Preciado, the playboy bed enveloped this capsular, prosthetic structure in an architecture of power that originated in the traditional purpose of the royal bed up until the 18th Century. (34)

This article outlines the relationship between the mindset of society, the layout of the house and the zoning of the city on the one hand, and the configuration of the bed at two specific ideological turning points. Information and communication technology affect all aspects of inhabitation and open up a field of research about the smart bed uncoupled from the bedroom that prompts a pressing need to undertake a journey, but in this instance, a 'journey around the bed'. (35) 


\section{NOTAS}

1. PERROT, Michelle. Historia de las alcobas. Madrid: Siruela, 2011, p. 8. 2. Expresión traducida por el autor: "Industrialization brought with the eight-hour shift and the radical separation between home and office / factory, rest and work, night and day. Post-industrialization collapses work back into the home and takes it further into the bedroom and into the bed itself". COLOMINA, Beatriz. 'The Century of the bed' (Introducción). En: VV. AA.; COLOMINA, Beatriz (com.). The Century of the bed. Vienna: Verlag fur moderne Kunst Nurnberg, 2014, p. 19. 3. RYBCZYNSKI, Witold. La casa. Historia de una idea, San Sebastián: Nerea, 2009.

4. ARIÈS, Phillippe; DUBY, George. Historia de la vida privada 5. El proceso de cambio en la sociedad de los siglos XVI-XVIII. Madrid: Taurus, 1993.

5. PERROT, Michelle. Op. cit., 2011.

6. MONTEYS, Xavier. La habitación. Más allá de la sala de estar.

Barcelona: Gustavo Gili, 2014.

7. DIBIE, Pascal. Etnología de la alcoba: el dormitorio y la gran aventura del reposo a lo largo del tiempo y las diferencias culturales. Barcelona: Gedisa, 1989.

8. COLOMINA, Beatriz. Op. cit., 2014.

9. RILEY, Terence (com.). The Un-Private House. (Celebrada en Nueva York, The Museum of Modern Art, del 1 de julio y al 5 de octubre de 1999). Nueva York: The Museum of Modern Art, 1999.

10. DIBIE, Pascal. Op. cit.,1989, p. 66.

11. RYBCZYNSKI, Witold. Op. cit., 2009, p. 50.

12. LUKACS, John. 'The bourgois interior'. En: The American Scholar. 1970, vol. 39, n. 4, p. 624.

13. ARIÈS, Phillippe; DUBY, George. Op. cit., 1993, p. 214.

14. PERROT, Michelle. Op. cit., 2011, pp. 38-40.

15. DIBIE, Pascal. Op. cit., 1989, p. 130.

16. RILEY, Terence. Op. cit., 1999, p. 11.

17. El pasillo permitió "una compartición individual para poder proteger al yo del resto". EVANS, Robin. Traducciones. Valencia: Pre-textos, 2005, pp. 87-90.

18. AURELI, P. Vittorio; TATTARA, Martino. Loveless: The Minimum

Dwelling and its Discontents. Milán: Black Square, 2019, p. 6.

19. PERROT. Op. cit., 2011, p. 76-80.

20. MONTEYS. 2014, pp. 8-11.

21. DIBIE, Pascal. Op. cit., 1989, pp. 68.

22. ÁBALOS, Iñaki. La buena vida. Visita guiada a las casas de la modernidad. Barcelona: Gustavo Gili, 2000, p. 22.

23. AURELI, P. Vittorio; TATTARA, Martino. 'Soft cell: the minimim dwelling. En: The Architectural Review, n. 1453, 2018, pp. 107-111. 24. PEDRET, Annie. CIAM and the emergence of Team 10 Thinking, 1945-1959. Tesis doctoral, Massachusetss Institute of Technology, 2001, pp. 126-155.

25. COLOMINA, Beatriz. 'Un aire aún no respirado, 1956' En: VAN DEN HEUVEL, D. y RISSELADA, M. (ed.). Alison y Peter Smithson. De la casa del Futuro a la casa de hoy. Barcelona: Ediciones Polígrafa, 2007, pp. 47-79. 26. COLOMBO, Joe. 'A vip house of a vip designer'. En: Domus, vol. 494, 1971, pp. 21-25.

27. PRECIADO, Beatriz. Pornotopía. Arquitectura y sexualidad en Playboy durante la guerra fría. Barcelona: Editorial Anagrama, 2010, p. 151.

28. COLOMINA, Beatriz. Op. cit., 2014, pp. 21-22.

29. ITO, Toyo. Escritos. Murcia: COAT Murcia, 2000, p. 62.

30. ÁBALOS, Iñaki. Op. cit., 2000, p.152.

31. COLOMINA, Beatriz. Op. cit., 2014, p. 21.

32. PERROT, Michelle. Op. cit., 2011, p. 439.

33. RILEY, Terence. Op. cit., 1999, p. 10.

34. PRECIADO, Beatriz. Op. cit., 2010, p. 169.

35. En alusión a la obra de Xavier de Maistre, Viaje alrededor de mi habitación. Y a la cita: "el viaje alrededor de la habitación se convierte en viaje alrededor del universo. Así conectada y revivificada, la habitación tiene ante sí muy buenos tiempos y exploraciones infinitas". PERROT, Michelle. Op. cit., 2011, p. 447.
NOTES

1. PERROT, Michelle. Historia de las alcobas. Madrid: Siruela, 2011, p. 8. 2. COLOMINA, Beatriz. 'The Century of the bed' (Introduction). In:

VV. AA.; COLOMINA, Beatriz (curator). The Century of the bed.

Vienna: Verlag fur moderne Kunst Nurnberg, 2014, p. 19.

3. RYBCZYNSKI, Witold. La casa. Historia de una idea, San Sebastian: Nerea, 2009.

4. ARIÈS, Phillippe; DUBY, George. Historia de la vida privada 5 . El proceso de cambio en la sociedad de los siglos XVI-XVIII. Madrid: Taurus, 1993.

5. PERROT, Michelle. Op. cit., 2011.

6. MONTEYS, Xavier. La habitación. Más allá de la sala de estar.

Barcelona: Gustavo Gili, 2014.

7. DIBIE, Pascal. Etnología de la alcoba: el dormitorio y la gran aventura del reposo a lo largo del tiempo y las diferencias culturales. Barcelona:

Gedisa, 1989.

8. COLOMINA, Beatriz. Op. cit., 2014.

9. RILEY, Terence (curator). The Un-Private House. New York:

The Museum of Modern Art, 1 July to 5 October 1999.

10. DIBIE, Pascal. Op. cit., 1989, p. 66.

11. RYBCZYNSKI, Witold. Op. cit., 2009, p. 50.

12. LUKACS, John. “The bourgeois interior”. In The American Scholar.

1970 , vol. 39 , n. 4 , p. 624 .

13. ARIÈS, Phillippe; DUBY, George. Op. cit., 1993, p. 214.

14. PERROT, Michelle. Op. cit., 2011, pp. 38-40.

15. DIBIE, Pascal. Op. cit., 1989, p. 130.

16. RILEY, Terence. Op. cit., 1999, p. 11.

17. The passage enabled "individual compartments in which to preserve the self from others". EVANS, Robin. Traducciones, Valencia: Pre-textos, 2005, pp. 87-90.

18. AURELI, Pier Vittorio; TATTARA, Martino. Loveless: The Minimum Dwelling and its Discontents. Milan: Black Square, 2019, p. 6.

19. PERROT, Michelle. Op. cit., 2011, pp. 76-80.

20. MONTEYS, Xavier. 2014, pp. 8-11.

21. DIBIE, Pascal. Op. cit., 1989, p. 68.

22. ÁBALOS, Iñaki. La buena vida. Visita guiada a las casas de la modernidad. Barcelona: Gustavo Gili, 2000, p. 22.

23. AURELI, Pier Vittorio; TATTARA, Martino. 'Soft cell: the minimum dwelling'. In The Architectural Review, n. 1453, 2018 , pp.107-111.

24. PEDRET, Annie. CIAM and the emergence of Team 10 Thinking, 1945-1959. PhD dissertation, Massachusetts Institute of Technology, 2001, pp. 126-155.

25. COLOMINA, Beatriz. 'Un aire aún no respirado, 1956'. In: VAN DEN HEUVEL, D. and RISSELADA, M. (ed.). Alison y Peter Smithson. De la casa del Futuro a la casa de hoy. Barcelona: Ediciones Polígrafa, 2007, pp. 47-79.

26. COLOMBO, Joe. 'La Casa Vip di un designer Vip'. In: Domus, vol. 494, 1971, pp. 21-25.

27. PRECIADO, Beatriz. Pornotopía. Arquitectura y sexualidad en Playboy durante la guerra fría. Barcelona: Editorial Anagrama, 2010, p. 151.

28. COLOMINA, Beatriz. Op. cit., 2014, pp. 21-22.

29. ITO, Toyo. Escritos. Murcia: COAT Murcia, 2000, p. 62.

30. ÁBALOS, Iñaki. Op. cit., 2000, p. 152.

31. COLOMINA, Beatriz. Op. cit., 2014, p. 21.

32.PERROT, Michelle. Op. cit., 2011, p. 439.

33. RILEY, Terence. Op. cit., 1999, p. 10.

34. PRECIADO, Beatriz. Op. cit., 2010, p. 169.

35. In reference to the book by Xavier de Maistre, Viaje alrededor de mi habitación and the quotation "el viaje alrededor de la habitación se convierte en viaje alrededor del universo. Así conectada y revivificada, la habitación tiene ante sí muy buenos tiempos y exploraciones infinitas" (The journey around the room becomes a journey around the universe. A bright future and countless explorations await the connected, resurrected room). PERROT, Michelle. Op. cit., 2011, p. 447. 


\section{REFERENCIAS}

ÁBALOS, Iñaki. La buena vida. Visita guiada a las casas de la modernidad. Barcelona: Gustavo Gili, 2000.

ARIÈS, Phillippe y DUBY, George. Historia de la vida privada 5 . El proceso de cambio en la sociedad de los siglos XVI-XVII. Madrid: Taurus, 1993. AURELI, P. Vittorio; TATTARA, Martino. 'Soft cell: the minimum dwelling. The Architectural Review, vol. 1453, 2018, pp. 107-111. AURELI, P. Vittorio; TATTARA, Martino. Loveless: The Minimum Dwelling and its Discontents. Milán: Black Square, 2019.

COLOMBO, Joe. 'A vip house of a vip designer'. En: Domus, vol. 494, 1971, pp. 21-25.

COLOMINA, Beatriz. 'Un aire aún no respirado'. En: VAN DEN HEUVEL, Dirk; RISSELADA, Max. (ed.). Alison y Peter Smithson. De la casa del Futuro a la casa de hoy. Barcelona: Ediciones Polígrafa, 2007, pp. 47-79. COLOMINA, Beatriz; RUMPFHUBER, Andreas; RUHS, August. Curated by Vienna. The Century of the Bed. Viena: Verlag fur moderne Kunst Nurnberg, 2014.

DIBIE, Pascal. Etnología de la alcoba: el dormitorio y la gran aventura del reposo a lo largo del tiempo y las diferencias culturales. Barcelona: Gedisa, 1989.

EVANS, Robin. Traducciones. Valencia: Pre-textos, 2005.

ITO, Toyo. Escritos. Murcia: COAT Murcia, 2000.

LUKACS, John. 'The bourgois interior'. The American Schoolar, vol. 39, n. ${ }^{\circ}$, 1970, pp. 616-630.

MONTEYS, Xavier. La habitación. Más allá de la sala de estar. Barcelona: Gustavo Gili, 2014.

PEDRET, Annie. CIAM and the emergence of Team 10 Thinking, 1945 -

1959. Tesis doctoral. Massachusetss Institute of Technology, 2001. PERROT, Michelle. Historia de las alcobas. Madrid: Siruela, 2011. PRECIADO, Beatriz. Pornotopía. Arquitectura y sexualidad en Playboy durante la guerra fría. Barcelona: Editorial Anagrama, 2010.

RILEY, Terence (com.). The Un-Private House. (Celebrada en Nueva York, The Museum of Modern Art, del 1 de julio al 5 de octubre de 1999). Nueva York: The Museum of Modern Art, 1999.

RYBCZYNSKI, Witold. La casa. Historia de una idea. San Sebastián: Nerea, 2009.

\section{REFERENCES}

ÁBALOS, Iñaki. La buena vida. Visita guiada a las casas de la modernidad. Barcelona: Gustavo Gili, 2000.

ARIĖS, Phillippe and DUBY, George. Historia de la vida privada 5 . El proceso de cambio en la sociedad de los siglos XVI-XVIII. Madrid: Taurus, 1993. AURELI, Pier Vittorio; TATTARA, Martino. 'Soft cell: the minimum dwelling. The Architectural Review, vol. 1453, 2018, pp. 107-111. AURELI, Pier Vittorio; TATTARA, Martino. Loveless: The Minimum Dwelling and its Discontents. Milan: Black Square, 2019.

COLOMBO, Joe. 'La casa Vip di un designer Vip'. In: Domus, vol. 494, 1971, pp. 21-25.

COLOMINA, Beatriz. 'Un aire aún no respirado' In: VAN DEN HEUVEL, Dirk; RISSELADA, Max. (ed.). Alison y Peter Smithson. De la casa del Futuro a la casa de hoy. Barcelona: Ediciones Polígrafa, 2007, pp.47-79. COLOMINA, Beatriz; RUMPFHUBER, Andreas; RUHS, August. Curated by Vienna. The Century of the Bed. Vienna: Verlag fur moderne Kunst Nurnberg, 2014.

DIBIE, Pascal. Etnología de la alcoba: el dormitorio y la gran aventura del reposo a lo largo del tiempo y las diferencias culturales. Barcelona: Gedisa, 1989.

EVANS, Robin. Traducciones. Valencia: Pre-textos, 2005. ITO, Toyo. Escritos. Murcia: COAT Murcia, 2000.

LUKACS, John. 'The bourgeois interior'. The American Scholar, vol. 39, n. 4, 1970, pp. 616-630.

MONTEYS, Xavier. La habitación. Más allá de la sala de estar.

Barcelona: Gustavo Gili, 2014.

PEDRET, Annie. CIAM and the Emergence of Team 10 Thinking, 19451959. PhD dissertation. Massachusetts Institute of Technology, 2001. PERROT, Michelle. Historia de las alcobas, Madrid: Siruela, 2011). PRECIADO, Beatriz. Pornotopía. Arquitectura y sexualidad en Playboy durante la guerra fría. Barcelona: Editorial Anagrama, 2010.

RILEY, Terence (curator). The Un-Private House (Exhibition in New York, The Museum of Modern Art, 1 July - 5 October 1999). New York: The Museum of Modern Art, 1999.

RYBCZYNSKI, Witold. La casa. Historia de una idea. San Sebastián: Nerea, 2009. 


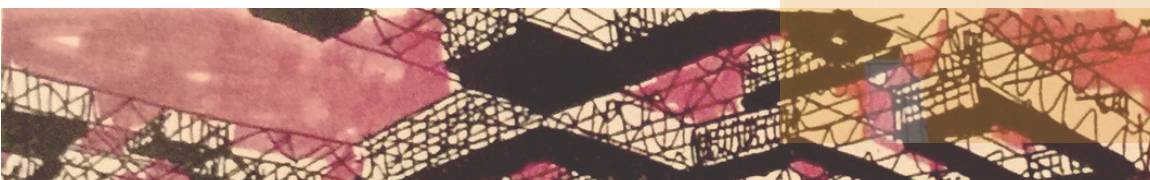

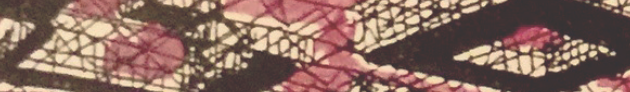

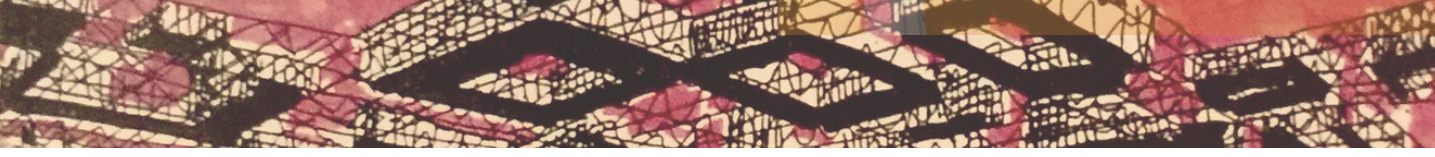
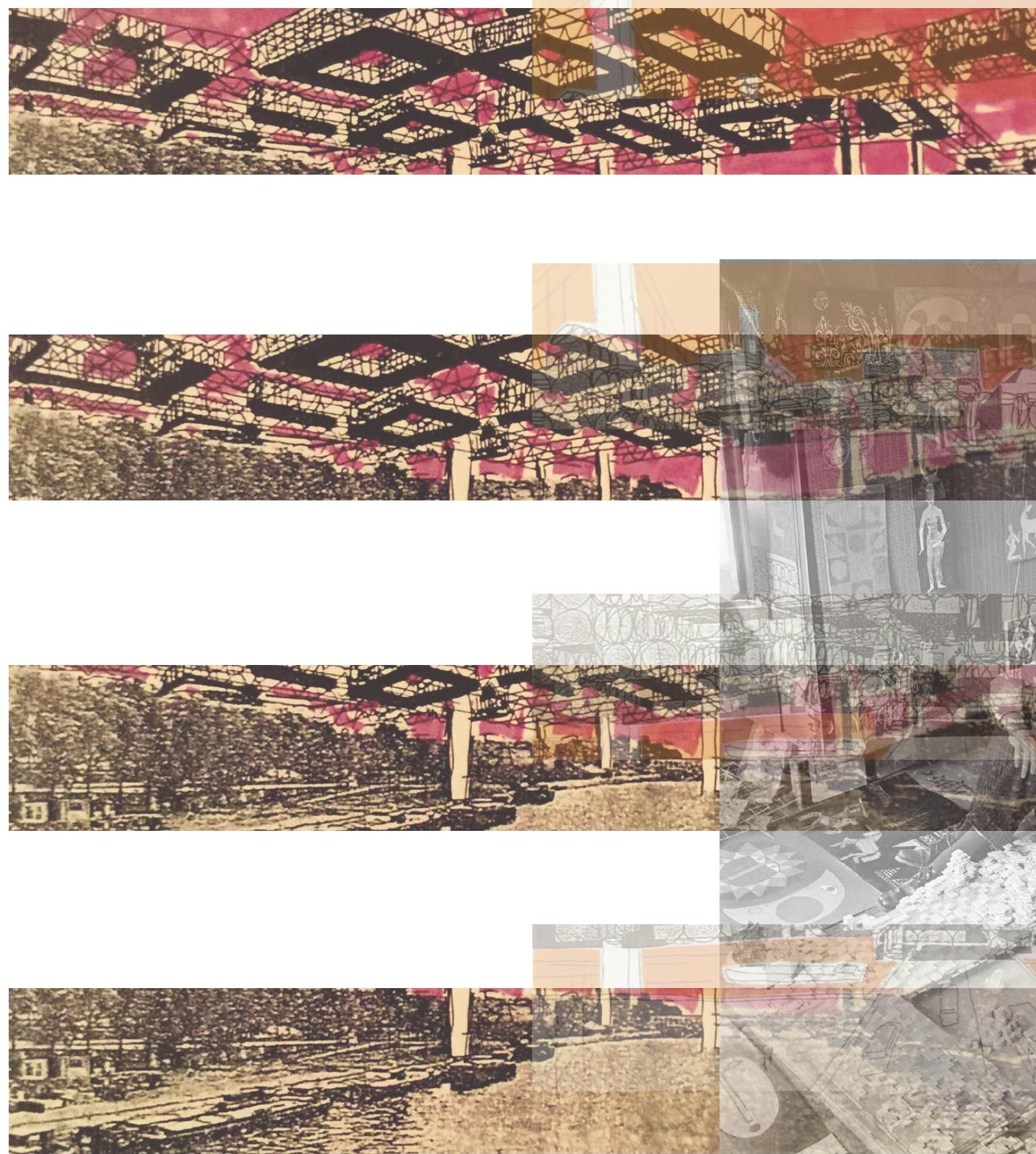